\title{
Killer Immunoglobulin like Receptor-Human Leukocyte Antigen Ligand Match/Mismatch in Graft Loss Post Transplant Cyclophosphamide Based Hap loidentical Transplant
}

Selma Zenia D'Silva ${ }^{1}$, Pankaj Diwedi ${ }^{2}$, Sachin Punatar ${ }^{2}$, Anant Gokarn ${ }^{2}$, Avinash Bonda $^{2}$, Manisha Tambe ${ }^{1}$, Sunil B. Rajadhyaksha $^{1}$, Navin Khattry ${ }^{2}$ and Meenakshi Singh ${ }^{1 *}$

${ }^{1}$ Department of Transfusion Medicine, HLA and Immunogenetics laboratory, Tata Memorial Hospital, Parel, Mumbai India

${ }^{2}$ Bone Marrow Transplant Unit, Advanced Centre for Treatment Research and Education in Cancer, Tata Memorial Centre, Kharghar, Navi Mumbai, India

\begin{abstract}
Background: Killer Immunoglobulin like receptor (KIR) genes that modulate Natural Killer cell alloreactivity have been linked with predicting haploidentical hematopoietic stem cell transplant outcomes.
\end{abstract}

Study design and methods: We present two haploidentical hematopoietic stem cell transplant (HHSCT) scenarios, wherein after engraftment there was graft loss. We hypothesized that this phenomenon was due to KIR ligand matches/mismatches. The KIR ligand matches/mismatches were examined in both patient donor pairs.

Results: Patient 1 and 2 were 11/12 and 12/12 match for HLA A, B, C, DRB1, DQB1 and DPB1 in GvH respectively, and their donors were 6/12 and 7/12 HLA match in HvG directions. It was observed that there was KIR activating receptor (aKIR) match and stronger KIR inhibitory receptor (iKIR) mismatch in GvH direction which resulted in removal of leukemic cells. Moreover, in the HvG direction, the stronger aKIR match led to graft rejection.

Conclusion: This study highlights the implication of KIR-HLA interaction in predicting graft survival.

Keywords: Hematopoietic stem cell transplantation; HLA-KIR ligand; graft rejection; Killer-immunoglobulin like receptor

Abbreviations: KIR: Killer Immunoglobulin like Receptor; $\mathrm{HH}-$ SCT: Haploidentical Hematopoietic Stem Cell Transplant; aKIR: KIR Activating Receptor; iKIR: KIR Inhibitory Receptor; GvH: Graft vs Host; HvG: Host vs Graft; GvL: Graft vs Leukemia; Ph+: Philadelphia Positive; ALL: Acute Lymphoblastic Leukemia; CML: Chronic Myeloid Leukemia; TBI: Total Body Irradiation; GVHD: Graft Versus Host Disease; MMF: Mycophenolate Mofetil; HSCT: Hematopoietic Stem Cell Transplant

\section{Introduction}

Haploidentical hematopoietic stem cell transplantation is one of the treatment option for leukemic patients who do not find a full HLA matched donor [1]. NK cells are the first cells against tumors and viral infections which act by suppressing or amplifying the $\mathrm{T}$ cell alloreactivity and play a major role in transplant outcomes. NK cells express a group of glycoproteins on their surface known as Killer immunoglobulin-like receptors (KIRs). NK cells are regulated by a net balance of activating and inhibitory signals that fine tune potent effector functions, such as cytolytic activity. Human NK cells express inhibitory and activating killer cell immunoglobulin like receptors (iKIRs and aKIRs) that recognize specific HLA class I alleles ("KIR ligands") [2]. The KIRs can either be inhibitory or activating receptors based on the length of the intracytoplasmic tail; long intracytoplasmic domain (L) is denoted as inhibitory iKIR, and a short intracytoplasmic domain (S) as activating KIR (aKIR), with an exception of KIR2DL4 which can be both inhibitory as well as activating [3]. The HLA ligand for inhibitory KIR2DL1 is HLA C2 (stronger inhibition), KIR2DL2/3 is HLA C1 (weaker inhibition), KIR3DL1 is Bw4 and activating KIR2DS1 is HLA C2 (weaker activation), KIR2DS2 is HLA C1 (stronger activation) and KIR3DS1 is Bw4 [4-6].

Recently, KIR receptors have been implied in predicting transplant outcomes [7-11]. Ligands for KIR receptors are the HLA Class I molecules, hence, HLA alleles of the patient and donor will predict a
KIR ligand ligand match/mismatch between the patient donor pair. When the patient is homozygous for HLA alleles and the donor is heterozygous, it suggests that there is a HLA haplotype mismatch between the patient-donor pair which in turn leads to KIR ligand ligand mismatch. When the mismatch is in the GvH direction, it leads to better GvL effect, however, when the mismatch is in the HvG direction it leads to the graft being recognized as foreign and hence removed from the host. Figure 1 explains this hypothesis based on HLA ligand-KIR receptor match/mismatch. In the graft vs host $(\mathrm{GvH})$ direction, if there is an increase in donor iKIR mismatch and a decrease in donor aKIR mismatch with patient HLA KIR ligand, it is expected that there would be more activation of NK cell activity which leads to removal of cancer cells, hence, lower relapse and increased overall survival. Whereas, in Host vs Graft (HvG) direction, an increase in aKIR mismatch and decrease or no iKIR mismatch (iKIR match) will result in lesser removal of graft cells (Figure 1).

\section{Materials and Methods}

Two patients, diagnosed as Philadelphia positive $(\mathrm{Ph}+)$ acute lymphoblastic leukemia (ALL) and chronic myeloid leukemia (CML) underwent HHSCT from their father and brother as donors, respectively.

*Corresponding author: Meenakshi Singh, Scientific Officer "D", HLA and Immunogenetics laboratory, Department of Transfusion Medicine, Tata Memorial Hospital, Parel, Mumbai-400012, India, Tel: +91-22-24127096; E-mail: meenakshisingha@gmail.com

Received September 20, 2018; Accepted September 24, 2018; Published September 28, 2018

Citation: D'Silva SZ, Diwedi P, Punatar S, Gokarn A, Bonda A, et al. (2018) Killer Immunoglobulin like Receptor-Human Leukocyte Antigen Ligand Match Mismatch in Graft Loss Post Transplant Cyclophosphamide Based Hap loidentical Transplant. J Blood Lymph 8: 225. doi: 10.4172/2165-7831.1000225

Copyright: @ 2018 D'Silva SZ, et al. This is an open-access article distributed under the terms of the Creative Commons Attribution License, which permits unrestricted use, distribution, and reproduction in any medium, provided the original author and source are credited. 
Citation: D'Silva SZ, Diwedi P, Punatar S, Gokarn A, Bonda A, et al. (2018) Killer Immunoglobulin like Receptor-Human Leukocyte Antigen Ligand Match/Mismatch in Graft Loss Post Transplant Cyclophosphamide Based Hap loidentical Transplant. J Blood Lymph 8: 225. doi: $10.4172 / 2165-7831.1000225$

(A)

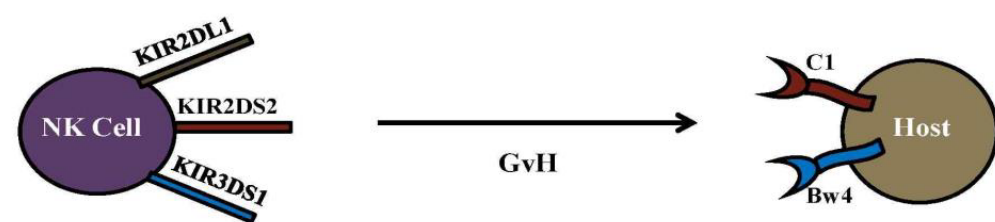

- Increased donor KIR inhibitory receptor mismatch with patient HLA Ligand

- Decreased donor KIR Activating receptor mismatch with patient HLA Ligand

- Results in more activation of NK cell activity and Lower inhibition

- Leads to removal of cancer cells, hence, lower relapse and increased overall survival

(B)

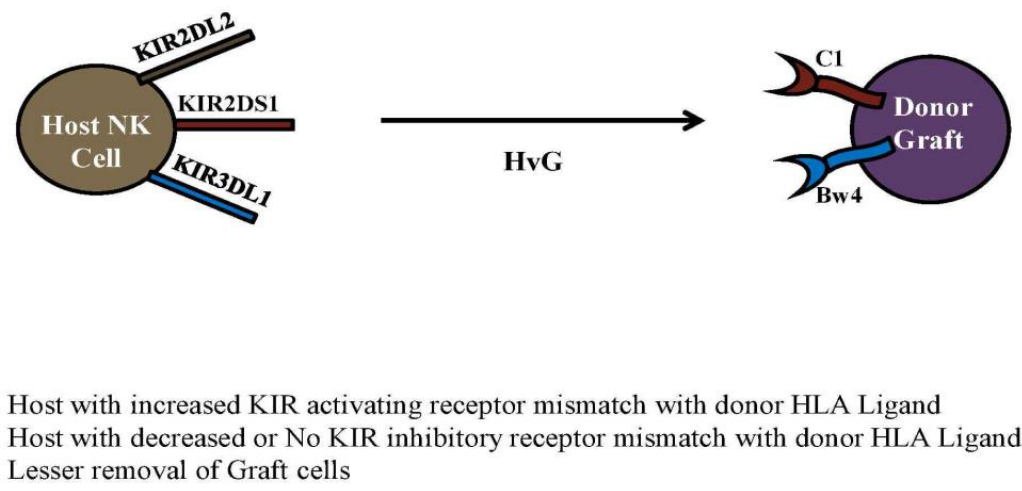

- Lesser removal of Graft cells

Figure 1: Hypothesis for successful engraftment and lower relapse. A) Graft vs Host (GvH) direction and B) Host vs Graft (HvG) direction.

Conditioning regimen used for $\mathrm{Ph}+\mathrm{ALL}$ was fludarabine $30 \mathrm{mg} /$ $\mathrm{m}^{2}$ for 5 days and melphalan $140 \mathrm{mg} / \mathrm{m}^{2}$ for 1 day. Patient with CML received fludarabine $30 \mathrm{mg} / \mathrm{m}^{2}$ for 5 days, treosulfan $14 \mathrm{~g} / \mathrm{m}^{2}$ for 3 days and 2 Gy total body irradiation (TBI) for 1 day. Graft versus host disease (GVHD) prophylaxis for both patients was cyclophosphamide $(50$ $\mathrm{mg} / \mathrm{kg})$ on $3^{\text {rd }}$ and $4^{\text {th }}$ day post-transplant followed by cyclosporine ( 1 patient) and tacrolimus (1 patient) with mycophenolate mofetil (MMF) from $5^{\text {th }}$ day post-transplant. Neutrophil and platelet engraftment occurred on Day 14 and Day 17 respectively for patient 1 and Day 16 in patient 2. Peripheral blood chimerism for both patients was $100 \%$ donor on day 14 and 28 post transplant. Slippage of chimerism began from Day 90 for patient 1 and Day 60 for patient 2 and graft was lost by $\mathrm{D}+90$ for patient 1 and 2 months post transplantation for patient 2 respectively. 
Citation: D'Silva SZ, Diwedi P, Punatar S, Gokarn A, Bonda A, et al. (2018) Killer Immunoglobulin like Receptor-Human Leukocyte Antigen Ligand Match/Mismatch in Graft Loss Post Transplant Cyclophosphamide Based Hap loidentical Transplant. J Blood Lymph 8: 225. doi: $10.4172 / 2165-7831.1000225$

Page 3 of 4

While the $\mathrm{Ph}+\mathrm{ALL}$ patient remains in remission with autologous recovery, patient with CML had relapse of chronic phase.

\section{HLA and KIR genotyping}

DNA was extracted using the salting out method (Bag Diagnostics, Germany). In both the patients and donors, high resolution HLA typing for HLA A, HLA B, HLA C, HLA DRB1, HLA DQB1 and HLA DPB1 was carried out using the Sequence based typing method (GenDx, Netherlands). KIR ligands were assigned to patients using the algorithm available on the KIR Ligand calculator tool (HLA Informatics Group of the Anthony Nolan Research Institute (http:// www.ebi.ac.uk/ipd/kir/)). KIR genotyping for $16 \mathrm{KIR}$ genes (KIR3DL3, KIR2DS2, KIR2DL2, KIR2DL3, KIR2DL5A/B, KIR2DS3/2DS5, KIR2DP1, KIR2DL1, KIR3DP1, KIR2DL4, KIR3DS1, KIR2DS1, KIR2DS4, and KIR3DL2) was carried out by PCR-SSP method using a ready available kit (Bag Diagnostics, Germany) as per manufactures instructions. Informed consent was taken for both patient donor pairs for undergoing allogeneic haploidentical transplant.

\section{Results}

The HLA typing for the 2 patients and their donors is shown in Table 1 . For patient 1 and patient 2 there was $11 / 12$ and $12 / 12$ match for HLA in GvH respectively, and their donors were heterozygous, 6/12 and 7/12 HLA match in HvG directions. Both the donors carried the C1C2 HLA C epitope and the TT (Bw4) epitope. Both patients carried the $\mathrm{C} 2 \mathrm{C} 2 \mathrm{HLA} C$ epitope, however, patient 1 carried the T-I- (absence of Bw4 epitope) and patient 2 carried the TT (Bw4) epitope for HLA B.

For patient 1 , there was no post transplantation CMV reactivation, adenoviral or fungal infection. However, polyomavirus BK reactivation was observed in this patient $\left(1.6 \times 10^{4}\right.$ copies $/ \mathrm{ml}$ in blood sample and $3.3 \times 10^{9}$ copies $/ \mathrm{ml}$ in urine sample). Tacrolimus was discontinued in patient 1 and cyclosporine in patient 2 due to slippage of donor chimerism.

Table 2 below shows the aKIR and iKIR matches/mismatches among patients and donors in both $\mathrm{GvH}$ and $\mathrm{HvG}$ direction. For both patients, a strong aKIR match was not observed; however, there was a higher iKIR mismatch in the GvH direction, which leads to enhanced NK cell activity and hence better GvL, whereas in the HvG direction there was higher aKIR and weaker iKIR match (C1) between the patient and donor. This led to enhanced NK cell activity in the HvG direction, which resulted in the graft being recognized as foreign and being rejected.

\section{Discussion}

The importance of KIR alloreactivity has previously been reported in studies involving $\mathrm{T}$ cell deplete haploidentical transplants $[10,12,13]$. However, there are few reports highlighting the importance of KIR alloreactivity in T cell replete haploidentical transplants and more so transplants involving post-transplant cyclophosphamide for GVHD prophylaxis [12,14]. Recently, Bastos et al. [14] reported improved overall survival and relapse free survival in patient-donor pairs having iKIR and ligand mismatches in haploidentical T cell replete transplants.

Here we report two patients who engrafted with donor cells post-transplant but the graft cells were gradually removed from the host over a period of 3 months. Patient 1 did not relapse; however, there was autologous recovery of host cells. In patient 2, there was slippage of chimerism on Day 60 and relapse of the disease. Viral and

\begin{tabular}{|c|c|c|c|c|c|c|}
\hline & HLA A & HLA B & HLA C & HLA DRB1 & HLA DQB1 & $\begin{array}{l}\text { HLA } \\
\text { DPB1* }\end{array}$ \\
\hline Patient 1 & 01:01:01 G & 35:01:01 G & 04:01:01 G & $\begin{array}{l}14: 04: 01 \\
-\end{array}$ & 05:03:01 G & $\begin{array}{l}\text { 02:01:02 G } \\
13: 01: 01 \mathrm{G}\end{array}$ \\
\hline Donor 1 & $\begin{array}{l}\text { 01:01:01 G } \\
\text { 11:01:01 G }\end{array}$ & $\begin{array}{l}\text { 35:01:01 G } \\
44: 03: 02 \text { G }\end{array}$ & $\begin{array}{l}\text { 04:01:01 G } \\
\text { 07:01:01 G }\end{array}$ & $\begin{array}{l}\text { 07:01:01 G } \\
\text { 14:04:01 }\end{array}$ & $\begin{array}{l}\text { 02:01:01 G } \\
\text { 05:03:01 G }\end{array}$ & $\begin{array}{l}\text { 13:01:01 G } \\
26: 01: 02\end{array}$ \\
\hline Patient 2 & $\begin{array}{l}\text { 02:35:01 } \\
-\end{array}$ & 13:01:01 G & $\begin{array}{l}\text { 04:03:01 } \\
-\end{array}$ & $\begin{array}{l}\text { 11:01:01 G } \\
-\end{array}$ & 03:01:01 G & 01:01:01 G \\
\hline Donor 2 & $\begin{array}{l}\text { 02:35:01 } \\
\text { 33:03:01 G }\end{array}$ & $\begin{array}{l}\text { 13:01:01 G } \\
40: 06: 01 \mathrm{G}\end{array}$ & $\begin{array}{l}\text { 04:03:01 } \\
\text { 08:01:01 G }\end{array}$ & $\begin{array}{l}11: 01: 01 \text { G } \\
12: 02: 01 \text { G }\end{array}$ & 03:01:01 G & $\begin{array}{l}01: 01: 01 \mathrm{G} \\
02: 01: 02 \mathrm{G}\end{array}$ \\
\hline
\end{tabular}

Table 1: High resolution HLA typing of patient and donors.

\begin{tabular}{|c|c|c|c|c|}
\hline \multirow[t]{2}{*}{ Patient 1 and 2} & GVH Direction & & & \\
\hline & Activating KIR receptor in donor & HLA Ligand in the patient & Match/Mismatch & \\
\hline & 2DS1 & $\mathrm{C} 2$ & Match & \multirow[t]{2}{*}{ Weaker AKIR match } \\
\hline & 2DS2 & No ligand present & Mismatch & \\
\hline & Inhibitory KIR receptor in donor & HLA Ligand in the patient & Match/Mismatch & \\
\hline & 2DL1 & $\mathrm{C} 2$ & Match & \multirow[t]{4}{*}{ Higher IKIR mismatch } \\
\hline & 2DL2 & No ligand present & Mismatch & \\
\hline & 2DL3 & No ligand present & Mismatch & \\
\hline & 3DL1 & No ligand present & Mismatch & \\
\hline & \multicolumn{3}{|l|}{ HVG Direction } & \\
\hline & Activating receptor in the patient & HLA Ligand in the donor & Match/Mismatch & \\
\hline & 2DS1 & $\mathrm{C} 2$ & Match & \multirow[t]{3}{*}{ Higher AKIR match } \\
\hline & 2DS2 & C1 & Match & \\
\hline & 2DS3 & C1 & Match & \\
\hline & Inhibitory receptor in the patient & HLA Ligand in the donor & Match/Mismatch & \\
\hline & 2DL2 & C1 & Match & \multirow[t]{2}{*}{ Weaker IKIR match } \\
\hline & 3DL1 & TT & Match & \\
\hline
\end{tabular}

Abbreviations: GvH: Graft vs Host; HvG: Host vs Graft; HLA: Human Leukocyte Antigen; KIR: Killer Immunoglobulin like receptors.

Table 2: KIR receptor-HLA Ligand matches/mismatches observed in the patients and donors in both GvH and HvG direction. 
Citation: D'Silva SZ, Diwedi P, Punatar S, Gokarn A, Bonda A, et al. (2018) Killer Immunoglobulin like Receptor-Human Leukocyte Antigen Ligand Match/Mismatch in Graft Loss Post Transplant Cyclophosphamide Based Hap loidentical Transplant. J Blood Lymph 8: 225. doi: $10.4172 / 2165-7831.1000225$

Page 4 of 4

bacterial infections are a common complication of HSCT and may also contribute to graft loss in the post engraftment stage. However, in both the patients the viral and bacterial history was uneventful.

Both patients underwent haploidentical transplant wherein the HLA disparity between the patient and donor results in selection of either activating/inhibitory KIR mismatch in the HvG direction which drives graft loss. In the $\mathrm{GvH}$ direction, there was $11 / 12$ and $12 / 12$ HLA match for the patients respectively. In the HvG direction, both the patients had a HLA haplotype match (6/12 and 7/12), with their respective donors, which could implicate the role of HLA in graft rejection. However, since there was no primary rejection it could implicate a role of non-HLA factor in the rejection of the graft.

Based on our KIR receptor-ligand hypothesis for a lower relapse, there should be higher activating KIR receptor-HLA ligand match and inhibitory KIR receptor-HLA ligand mismatch in the GvH direction. In both the patients, we report an aKIR match and stronger iKIR mismatch in $\mathrm{GvH}$ direction resulting in the removal of the residual leukemic cells. Moreover, for maintenance of successful engraftment with no graft rejection, we hypothesize that there should be an increased aKIR mismatch and lower or no iKIR mismatch in the HvG direction. In the present study, in the HvG direction, there was a weak inhibitory KIR receptor ligand match (2DL2 and C1) and a stronger activating KIR receptor ligand match (KIR2S2 and C1; KIR2DS1 and C2) for both patients. In addition, there was a stronger inhibitor receptor ligand mismatch (KIR2DL1 and KIR2DL3 and ligand C2), due to which inhibition of host NK cell activity was lost, leading to the graft cells being recognized as foreign and resulting in secondary graft rejection.

In a separate retrospective analysis from our group involving 41 haplomatched and mismatched transplants, wherein, the effect of HLA mismatch in HvG direction along with KIR ligand receptor matches was compared to transplant outcomes, it was observed that only based on HLA disparity or on KIR receptor ligand match, haplomatched and mismatched transplants had similar overall survival, $(p=0.306$ and $\mathrm{p}=0.699$ respectively), however, when HLA disparity was present along with KIR mismatches it resulted in significantly better overall survival in haplotransplants as compared to mismatched transplants $(\mathrm{p}=0.05)$ (unpublished data).

The present study highlights that HLA mismatch led to inhibitory KIR ligand receptor mismatches in the $\mathrm{HvG}$, due to which there was loss of inhibition of host NK cells leading to loss of graft. Hence, we conclude that in homozygous patients with haploidentical donor, there is a combined effect of the HLA match and KIR receptor ligand match which decides graft survival.

\section{Acknowledgements}

This work was supported by the Terry fox International research grant and DST-WOSA grant.

\section{References}

1. Kanakry CG, Fuchs EJ, Luznik L (2016) Modern approaches to HLA haploidentical blood or marrow transplantation. Nat Rev Clin Oncol 13: 10-24.

2. Karre K, Ljunggren HG, Piontek G, Kiessling R (1986) Selective rejection of $\mathrm{H}$-2-deficient lymphoma variants suggests alternative immune defense strategy. Nature 319: 675-678.

3. Hsu KC, Chida S, Geraghty DE, Dupont B (2002) The killer cell immunoglobulinlike receptor (KIR) genomic region: gene order, haplotypes and allelic polymorphism. Immunol Rev 190: 40-52.

4. Rammal R, Haddad J, Mahfouz RA (2017) Killer cell Immunoglobulin-like Receptor (KIRs) and hematopoietic stem cell transplantation outcomes. A review of literature. Meta Gene 11: 5-13.

5. Faure M, Long EO (2002) KIR2DL4 (CD158d), an NK cell activating receptor with inhibitory potential. J Immunol 168: 6208-6214.

6. Kanga U, Mourya M, Seth T, George J, Sood P, et al. (2012) Role of Killer Immunogloculin-like Receptor-Ligand Interactions in Human Leukocyte Antigen-Matched Sibling Hematopoeitic Stem Cell Transplantation. Transplant Proc 44: 919-921.

7. Ferrara JLM (2000) Pathogenesis of acute graft-versus-host disease: cytokines and cellular effectors. J Hematother Stem Cell Res 9: 299-306.

8. Kayaba H, Hirokawa M, Watanabe A, Saitoh N, Changhao C, et al. (2000) Serum markers of graft- versus-host disease after bone marrow transplantation. J Allergy Clin Immunol 106: S40-S44.

9. Imamura M, Hashino S, Kobayashi H, Kubayashi S, Hirano S, et al. (1994 Serum cytokine levels in bone marrow transplantation: synergistic interaction of interleukin-6, interferon- $\gamma$, and tumor necrosis factor- $\alpha$ in graft-versus-host disease. Bone Marrow Transplant 13: 745-751.

10. Ruggeri L, Capanni M, Urbani E, Perruccio K, Sholmchik WD, et al. (2002) Effectiveness of donor natural killer cell alloreactivity in mismatched hematopoietic transplants. Science 295: 2097-3100.

11. Symons HJ, Leffell MS, Rossiter ND, Zahurak M, Jones RJ, et al. (2010) Improved survival with inhibitory killer immunoglobulin receptor (KIR) gene mismatches and KIR haplotype $B$ donors after nonmyeloablative, HLA-haploidentical bone marrow transplantation. Biol Blood Marrow Transplant 16: 533-542.

12. Ruggeri L, Mancusi A, Capanni M, Urbani E, Carotti A et al. (2007) Donor natural killer cell allorecognition of missing self in haploidentical hematopoietic transplantation for acute myeloid leukemia: challenging its predictive value. Blood 110: 433-440.

13. Leung W, lyengar R, Leimig T, Holladay MD, Houston J, et al. (2005) Phenotype and function of human natural killer cells purified by using a clinical-scale immunomagnetic method. Cancer Immunol Immunother 54: 389-394.

14. Bastos-Oreiro M, Anguita J, Martınez-Laperche C, Fernandez L, Buces E, et al. (2016) Inhibitory killer cell immunoglobulin-like receptor (iKIR) mismatches improve survival after T-cell-repleted haploidentical transplantation. European Journal of Haematology 96: 483-491. 